\title{
Rb/Sr WHOLE ROCK AGE DETERMINATIONS ON METAVOLCANIC ROCKS FROM THE NARSSARSSUAQ REGION, SOUTH GREENLAND
}

\section{Svend Pedersen, Jan H. Allaart and Ole Larsen.}

In the area of Julianehåb granite along the south-west coast of Greenland remnants of volcanic rocks are widespread. Well banded, intermediate tuffs occur on Mato and adjacent islands to the west of Julianehåb (Nesbitt, 1961; Allaart, 1967). Intermediate plagioclase-porphyritic rocks occur associated with aplitic gneiss north of Bredefjord. Two other important occurrences of volcanic rocks may be found in the high mountains north of Narssarssuaq close to the ice cap (Allaart, 1971).

All four occurrences of volcanic rocks are surrounded by late Ketilidian granites. These in turn are flanked to the north-west and south-east by older, early Ketilidian granite.

The metavolcanics of the Narssarssuaq region consist of acid and some intermediate porphyritic metavolcanic rocks, often with layers and lenses of epidote alternating with layers of pyroclastic rocks and aplitic gneiss. Thin calc-silicate layers and conglomerate horizons occasionally occur. The volcanic rocks and associated metasediments are generally foliated and in many places they show intricate fold structures. The field relations show that they have been affected by a complex series of events such as deformation, metamorphism, and recrystallisation. The volcanic rocks are clearly older than the surrounding late granites.

From the Narssarssuaq region five specimens were selected for $\mathrm{Rb} / \mathrm{Sr}$ whole rock isochron dating of the metavolcanic suite. One sample was selected from an intermediate plagioclase-porphyritic rock, one sample represents an acid pyroclastic rock and three samples were taken from acid metamorphosed lavas.

It was hoped that the age obtained would pre-date the surrounding late $\mathrm{Ke}$ tilidian granite and give an age that might be interpreted as either the age of an earlier metamorphic event or possibly the age of extrusion.

The age obtained, $1740 \pm 90$ m.y., coincides with the age of the late Ketilidian Julianehåb granite (Van Breemen et al., 1974) and indicates either that the strontium isotopes have completely equilibrated in response to the emplacement of the surrounding granites, or that the metavolcanics are closely related to the surrounding 


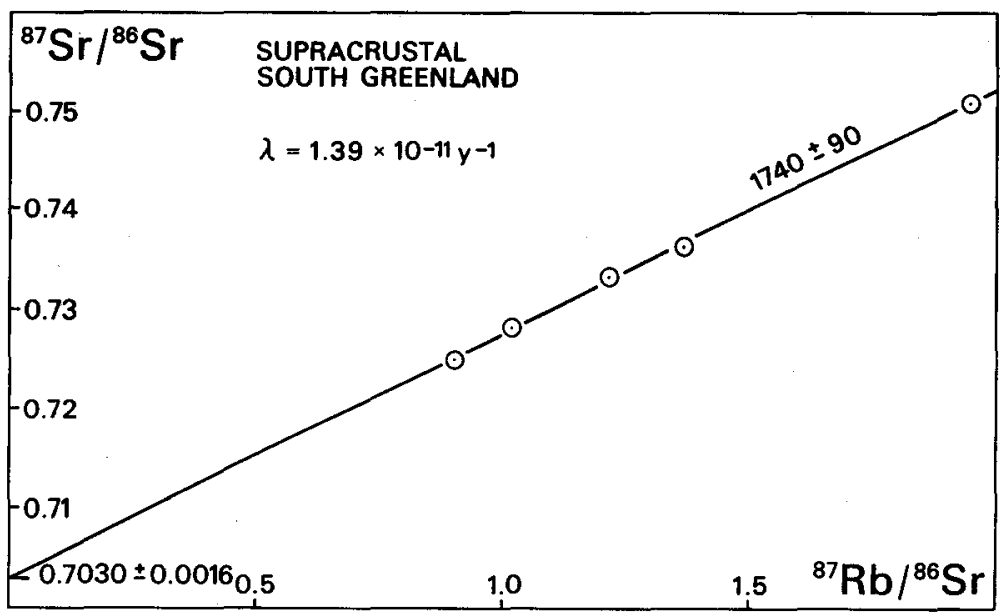

Fig. 11. Rb/Sr evolution diagram for whole-rock samples from the supracrustal rocks north of Narssarssuaq, South Greenland, listed in table 8.

Ketilidian granites. However, the low initial isotopic ratio of strontium of 0.7030 \pm 0.0016 for the metavolcanic rocks does not support a pre-metamorphic history in the crust of more than 100-150 m.y. Therefore, unless either early $\mathrm{Rb}$ depletion or preferential loss of radiogenic strontium occurred, maintaining a low initial strontium ratio during the last metamorphic event, the metavolcanics may be considered as equivalent to the Ketilidian volcanic suite from South-East Greenland and dated at 1850 m.y. (Pedersen et al., this report, p. 17).

The laboratory techniques and methods of calculation are the same as those employed by Pedersen et al., this report, p. 15.

Table 8. Analytical details of samples from the area north of Narssarssuaq, South Greenland

\begin{tabular}{clcc}
\hline GGU sample No. & \multicolumn{1}{c}{ Locality } & ${ }^{87} \mathrm{Rb} /{ }^{86} \mathrm{Sr}^{*}$ & ${ }^{87} \mathrm{Sr} /{ }^{86} \mathrm{Sr}$ \\
\hline 123597 & $61^{\circ} 25^{\prime} 30^{\prime \prime} \mathrm{N} ; 45^{\circ} 01^{\prime} \mathrm{W}$ & $0.90 \pm 0.03$ & $0.7250 \pm 0.0004$ \\
123615 & $61^{\circ} 26^{\prime} \mathrm{N} ; 44^{\circ} 57^{\prime} \mathrm{W}$ & $1.02 \pm 0.03$ & $0.7281 \pm 0.0003$ \\
123607 & $61^{\circ} 23^{\prime} 40^{\prime \prime} \mathrm{N} ; 45^{\circ} 04^{\prime} \mathrm{W}$ & $1.22 \pm 0.03$ & $0.7332 \pm 0.0004$ \\
123600 & $61^{\circ} 25^{\prime} 30^{\prime \prime} \mathrm{N} ; 44^{\circ} 59^{\prime} 30^{\prime \prime} \mathrm{W}$ & $1.37 \pm 0.03$ & $0.7361 \pm 0.0003$ \\
123614 & $61^{\circ} 26^{\prime} \mathrm{N} ; 44^{\circ} 57^{\prime} \mathrm{W}$ & $1.95 \pm 0.04$ & $0.7509 \pm 0.0003$ \\
\hline
\end{tabular}

$\left.\begin{array}{lr}\text { Initial ratio: } & 0.7030 \pm 0.0016 \\ \text { Age: } & 1740 \pm 90 \mathrm{~m} . \mathrm{y}\end{array}\right\} \begin{aligned} & \text { Errors given at the } \\ & 1 \sigma \text { confidence level }\end{aligned}$

Decay constant: $1.39 \times 10^{-11} \mathrm{y}^{-1}$

* $\mathrm{Rb} / \mathrm{Sr}$ ratios determined by XRF using the following $\mathrm{Rb} / \mathrm{Sr}$ ratios for USGS standards: GSP-1: 1.093 , G-2: 0.355 . 


\section{Petrographic descriptions of the samples}

GGU 123597. Plagioclase-porphyritic biotite-hornblende meta-diorite

Saussuritised plagioclase phenocrysts, 1-2 mm in length and occupying $40 \%$ of the rock volume, occur in a schistose matrix of biotite, hornblende, plagioclase and quartz. The schistosity is irregular and bends around the phenocrysts. Accessories are opaque minerals, microcline, epidote and apatite.

\section{GGU 123614, 123615. Meta-rhyodacite}

This pyroclastic rock shows a texture which is similar to the eutaxitic texture of ignimbrites (for nomenclature see Ross \& Smith, 1961). The recrystallised original fiamme fragments (123615) are white in colour and are up to several centimetres long. They consist of a granoblastic aggregate, averaging $0.15 \mathrm{~mm}$, of equal amounts of quartz, microcline and plagioclase, and accessory muscovite, biotite and opaque minerals.

The grey matrix (123614) is heterogeneous and foliate, still reflecting the original flow structure. Slightly oriented biotite flakes $(10-20 \%)$ average $0.3 \mathrm{~mm}$ in length. Quartz $(0.3$ $\mathrm{mm}$ ), and plagioclase and microcline (av. $0.2 \mathrm{~mm}$ ) form a granoblastic aggregate. Large often irregular muscovite crystals make up $5-10 \%$ of the rock volume. Opaque minerals are rare accessories.

\section{GGU 123607. Meta-rhyolite}

In this purplish red rock whitish stripes and lenses produce an irregular streaky pattern. Small, white plagioclase phenocrysts less than $1 \mathrm{~mm}$ in length are regularly distributed. Quartz (av. $0.1 \mathrm{~mm}$ ), microcline and plagioclase (av. $0.25 \mathrm{~mm}$ ) occur in granoblastic relation. The purplish colour is produced by kaolinisation of the feldspar and the presence of regularly distributed small opaque grains. The whitish streaks and stripes are unaltered and are relatively rich in microcline, poor in opaque grains and less fine grained than the purplish parts. Signs of deformation are practically absent in this rock.

\section{GGU 123600 Porphyritic meta-rhyolite}

In this light grey, very fine-grained rock occasional thin layers occur which are slightly coarser grained. Phenocrysts of plagioclase and microline, often intergrown with each other, occur in a matrix of quartz, acid plagioclase, microcline and well oriented mica flakes. The average grain size of the rock is less than $0.1 \mathrm{~mm}$. Streaks of biotite occur regularly. Most of the feldspar is sericitised and kaolinised. Accessories are opaque grains, titanite and apatite.

\section{References}

Allaart, J. H. 1967: Basic and intermediate igneous activity and its relationships to the evolution of the Julianehåb granite, South Greenland. Bull. Grønlands geol. Unders. 69 (also Meddr Grønland 175,1) 136 pp.

Allaart, J. H. 1971: Field investigations in the Julianehåb granite on the nunataks northwest, north and east of Narssarssuaq, South Greenland. Rapp. Grønlands geol. Unders. $35,23-25$.

Nesbitt, R. W. 1961: The petrology and structure of the country around Julianehåb, southwest Greenland. Unpublished Ph. D. thesis, Durham Univ., England.

Ross, C. S. \& Smith, R. L. 1961: Ash flow tuffs: their origin, geologic relations and identification. Prof. Pap. US geol. Surv. 366, 81 pp.

Van Breemen, O., Allaart, J. H. \& Aftalion, M. 1974: Isotopic and geochronological studies on granites in the Ketilidian mobile belt of South Greenland. Bull. geol. Soc. Amer. 85, 403-412. 